\title{
Kapasitas Adsorbansi Arang Aktif Kulit Kacang Tanah pada Penyisihan Logam Fe
}

\author{
Agil Harnowo, Miftahul Jannah, Euis Nurul Hidayah ${ }^{\text {a), }}$ \\ Teknik Lingkungan, Fakultas Teknik, UPN Veteran Jawa Timur \\ ${ }^{a)}$ Email korespondensi : euisnh.tl@upnjatim.ac.id
}

\begin{abstract}
ABSTRAK
Kulit kacang tanah sebagai limbah pertanian yang mengandung selulosa dinilai berpotensi sebagai adsorben untuk menyisihkan logam berat, oleh karena itu perlu dilakukan analisa kapasitas adsorbansi atau kemampuan jerat pada proses adsorpsi kontinyu dalam menyisihkan logam berat Fe pada air sumur. Adapun studi tentang kapasitas adsorbansi pada proses kontinyu umumnya dilakukan dengan pemodelan Thomas. Penelitian ini menggunakan proses adsorpsi kontinyu hingga didapatkan waktu jenuh dari adsorben kulit kacang tanah dalam menyerap logam Fe. Sehingga didapatkan kapasitas adsorbansi dari penggunaan sekali karbon aktif kulit kacang tanah yang telah dibuat. Pada penelitian ini dilakukan proses adsorpsi kontinyu dengan variasi massa 250 gr dan 500 gr. Pada proses adsorpsi kontinyu ini didapatkan harga Konstanta Thomas (Kth) dan harga kapasitas adsorbansi $\left(q_{\mathrm{o}}\right)$ tertinggi yakni menggunakan karbon aktif kulit kacang tanah dengan penggunaan sebanyak 500 gram yag mengikuti model persamaan Thomas $\mathrm{y}=-0.1701 \mathrm{x}+3.3142$ dengan koefisien determinasi $\left(\mathrm{R}^{2}\right)=$ 0.4767 sedangkan titik breakthrough dimana merupakan titik awal kembalinya konsentrasi akhir air dicapai pada menit ke-60 setelah air sumur melewati kolom adsorpsi.
\end{abstract}

Kata kunci : adsorpsi kontinyu; kulit kacang tanah; logam Fe; kurva breakthrough; Model Thomas.

\begin{abstract}
Cellulose contained in peanut shells which is agricultural waste is considered to be potential as an adsorbent for removing heavy metals. In that sense it is necessary to analyze the adsorbance capacity or the ability of meshes in the continuous adsorption process in removing heavy metal Fe. The study of the capacity of adsorbance in a continuous process is generally carried out using Thomas Model. In this study a continuous adsorption process was carried out to obtain saturation time from the adsorption of peanut shells in absorbing Fe metal. So that the adsorbance capacity obtained from the once used activated carbon peanut shell has been made. In this study a continuous adsorption process was carried out with a mass variation of $250 \mathrm{gr}$ and $500 \mathrm{gr}$. This continuous adsorption process is obtained. The highest value of Thomas Constant (Kth) and the value of adsorbance capacity (qo) is using peanut shell's activated carbon following the Thomas equation model $y=-0.1701 x+$ 3.3142 with a coefficient of determination $\left(R^{2}\right)=0.4767$ while the breakthrough point was reached in the 60th minute after well water through the bed.
\end{abstract}

Keywords: breakthrough curve; continuousa; Fe metal; peanut shells; Thomas Model.

\section{PENDAHULUAN}

Peningkatan produksi kacang tanah di Indonesia khususnya di Jawa Timur sebagai penghasil kacang tanah terbesar No.4 di Indonesia (Sagita,2017), menyebabkan peningkatan limbah pertanian yang berupa kulit kacang tanah yang sampai saat ini masih belum banyak dimanfaatkan. Disisi lain, telah banyak pencemaran yang terjadi akibat berbagai macam limbah salah satunya limbah pertanian, dan limbah laundry seperti yang kita tahu yakni pencemaran air tanah (Amalia et al., 2018). Metode adsorpsi sendiri merupakan salah satu unit proses yang dirasa lebih efektif dan sering digunakan dalam proses pengolahan air, karena ekonomis serta tidak menimbulkan efek samping yang beracun (Hidayati, Ulfin, \& Juwono, 2016).

Pada proses ini, dibutuhkan adsorben sebagai zat penjerap dan adsorbat berupa molekul terlarut yang terakumulasi pada permukaan adsorben oleh gaya van der waals (Susanti, 2009). Adsorben yang biasa digunakan yakni karbon aktif, dirasa memerlukan biaya produksi dan regenerasi yang tinggi, sehingga perlu dikaji lagi mengenai adsorben alternatif yang lebih efektif dan ramah lingkungan serta memiliki kapasitas adsorpsi yang cukup besar (Hidayati et al., 2016).

Selain itu, karbon aktif yang banyak digunakan tentu saja menimbulkan adanya polutan sekunder. Namun saat ini, telah banyak penelitian yang menyebutkan bahwa karbon aktif yang telah jenuh dapat diregenerasi kembali sehingga dapat digunakan untuk proses adsorpsi berulang baik regenerasi thermal (fisika) maupun secara kimiawi (Pricilia Duma Laura, 2014). Selain itu adsorben yang telah digunakan untuk meremoval logam berat, 
dapat dimanfaatkan dengan menjadikan arang aktif tersebut sebagai campuran dalam pembuatan batako, sehingga mampu menurunkan tingkat pencemaran sekunder akibat arang aktif hasil dari proses adsorpsi (Zuhroh, Prasetya, \& Haryani, 2016).

Beberapa penelitian yang telah dilakukan menggunakan arang aktif dari limbah pertanian khususnya limbah kulit kacang tanah hanya diaplikasikan sebagai penyerap zat warna industri (Susanti, 2009) atau arang briket (Dewati, Ragilia, Kharisma, \& Wahyusi, 2012), serta pemanfaatan dari limbah kulit kacang tanah sendiri masih sangat kurang. Padahal kulit kacang tanah pada kondisi kering mengandung selulosa 63,5\% (Lestari, Susatyo, \& Prasetya, 2017), dimana kandungan selulosa tersebut memiliki gugus karboksil dan hidroksil sehingga mampu mengikat ion logam (Safrianti, Wahyuni, \& Zaharah, 2012). Dalam penentuan kapasitas adsorpsi, sistem dinamis belum pernah diaplikasikan dengan kulit kacang tanah sebagai adsorbennya, padahal sistem dinamis atau kontinyu yang merupakan proses mengontakkan larutan dengan adsorben dirasa memiliki hasil yang lebih baik (Asnawati, 2017).

Penggunaan aktivasi juga bisa dijadikan sebagai metode perluasan pori-pori adsorben dalam meningkatkan kapasitas jerat adsorben . Adapun model yang dapat digunakan untuk menentukan kapasitas adsorpsi pada sistem kontinyu yakni persamaan Thomas yang merupakan model umum pada proses kontinyu dengan didasarkan pada data konsentrasi influen dan effluent, laju aliran pada flow process, serta waktu kontak larutan yang dilewatkan pada kolom adsorben (Asnawati, 2017). Performa dari adsorpsi kolom fixed-bed sendiri dapat dijelaskan dengan konsep kurva breakthrough. Dimana, waktu breakthrough dan bentuk dari kurva breakthrough merupakan karakteristik penting dalam menentukan pola operasi serta respon dinamis dari suatu kolom adsorpsi. Hal ini menghasilkan masa penggunaan dari adsorben dan waktu regenerasi serta secara langsung berpengaruh terhadap nilai ekonomi dari proses (Mizwar, 2016). Berdasarkan uraian diatas, sehingga untuk menentukan efektifitas penggunaan adsorben kulit kacang tanah sebagai penyisih logam Fe, waktu jenuh dari adsorben serta kapasitas jeratnya, maka dilakukan penelitian tentang kapasitas adsorbansi adsorben kulit kacang tanah dalam penyisihan logam berat Fe dengan sistem fixed bed column dengan menerapkan permodelan Thomas.

\section{METODE}

Penelitian ini menggunakan limbah kulit kacang tanah yang diarangkan dan diayak dengan ukuran \pm 50 mesh, sample air sumur di Kelurahan Sarirogo, Sidoarjo Aquades, larutan NaOH 0,001 M, seperangkat reaktor kolom adsorpsi $\emptyset_{10,5} \mathrm{~cm}$ dan tinggi $60 \mathrm{~cm}$ yang dilengkapi bak penampung dan pengatur debit. Arang aktif dari limbah kulit kacang tanah diuji kadar air dan kadar abu yang mengacu pada Standar Nasional Indonesia 063730-1995. Pada penelitian ini, tidak dilakukan pengukuran luas permukaan pori dan volume pori sehingga pada penelitian selanjutnya sangat disarankan untuk pengujian SEM EDX dalam mengetahui ukuran pori. Pada penelitian ini adsorpsi dilakukan dengan mengalirkan air sumur yang akan diolah yang berasal dari daerah Kelurahan Sarirogo, Kecamatan Sidoarjo,Kabupaten Sidoarjo, dengan debit 0,2 L/menit dan dengan variasi massa adsorben 250 gr dan 500 gr dan dengan penggunaan adsorben karbon aktif kulit kacang tanah. Penelitian dilakukan dengan system aliran dari atas ke bawah (downflow). Berikut Gambar 1 merupakan kolom adsorpsi yang digunakan : 5

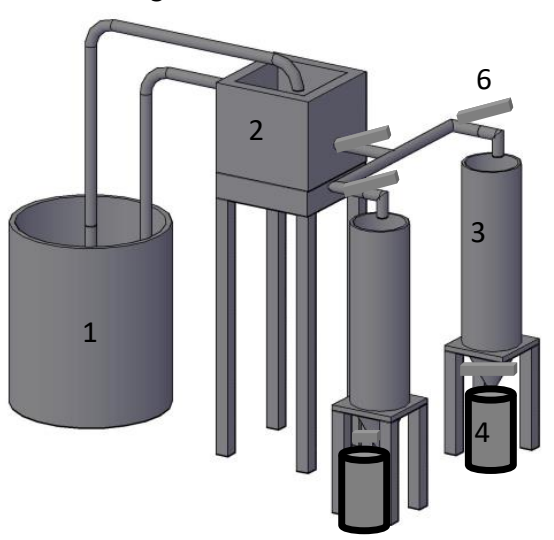

Keterangan :

1. Bak penampung sampel

2. Bak pengatur debit.

3. Kolom Adsorpsi

4. Penampung Effluent

5. Pipa overflow rate

6. Valve

Gambar 1. Set desain kolom kerja

Kajian kinetika kapasitas adsorpsi dilakukan dengan menggunakan data kesetimbangan adsorpsi yang diperoleh pada berbagai waktu sampling. Dalam evaluasi ini, data yang diperoleh diuji untuk menentukan bentuk linear persamaan kinetika (kapasitas adsorspsi) yang sesuai dalam proses adsorpsi dengan menggunakan persamaan 
Model Thomas yang memang umum digunakan pada proses adsorpsi kontinyu. Adapun model yang digunakan dapat dilihat pada Persamaan 1.

$$
\operatorname{Ln}\left[\frac{C o}{C_{t}}-1\right]=\frac{K_{t h} q_{0} x}{Q}-K_{t h} C_{0} t
$$

Dengan:

$\begin{array}{ll}\text { KTh } & \text { : Konstanta Thomas (L/mg/menit) } \\ \text { qo } & \text { : kapasitas adsorpsi (mg/gr) } \\ \text { X } & \text { : Massa adsorben }(\mathrm{gr}) \\ \text { Q } & : \text { Laju alir (L/menit) } \\ \text { Co } & \text { : Konsentrasi awal (mg/L) } \\ \text { t } & \text { : waktu (menit) } \\ \text { Ct } & \text { : Konsentrasi akhir (mg/L) }\end{array}$

(Biswas \& Mishra, 2015)

\section{HASIL DAN PEMBAHASAN}

\subsection{Pengaruh Variasi Massa pada Penyisihan Besi}

Berdasarkan analisa awal yang telah dilakukan, kadar logam Fe pada air sumur khususnya di daerah Kelurahan Sarirogo Kabupaten Sidoarjo sebesar 2,07 mg/L. Konsentrasi tersebut melebihi baku mutu, yaitu 0,3 mg/L. Kadar besi yang melebihi baku mutu ini apabila dikonsumsi diperlukan pengolahan terlebih dahulu. Pada penelitian yang selalu dilakukan menggunakan spesifikasi air ini, berupa proses filtrasi maupun aerasi (Susilawaty, Amansyah, \& Jumiati, 2015). Akan tetapi, semakin bertambahnya nilai Fe pada air sumur ini, maka diperlukan pengolahan yang lebih mudah dan efisien serta dengan adanya proses adsorpsi ini juga diharapkan dapat berperan sebagai minimalisasi limbah pertanian yang ada dilingkungan. Berdasarkan penelitian yang dilakukan, hasil penyisihan Fe ditunjukkan pada Gambar 2.

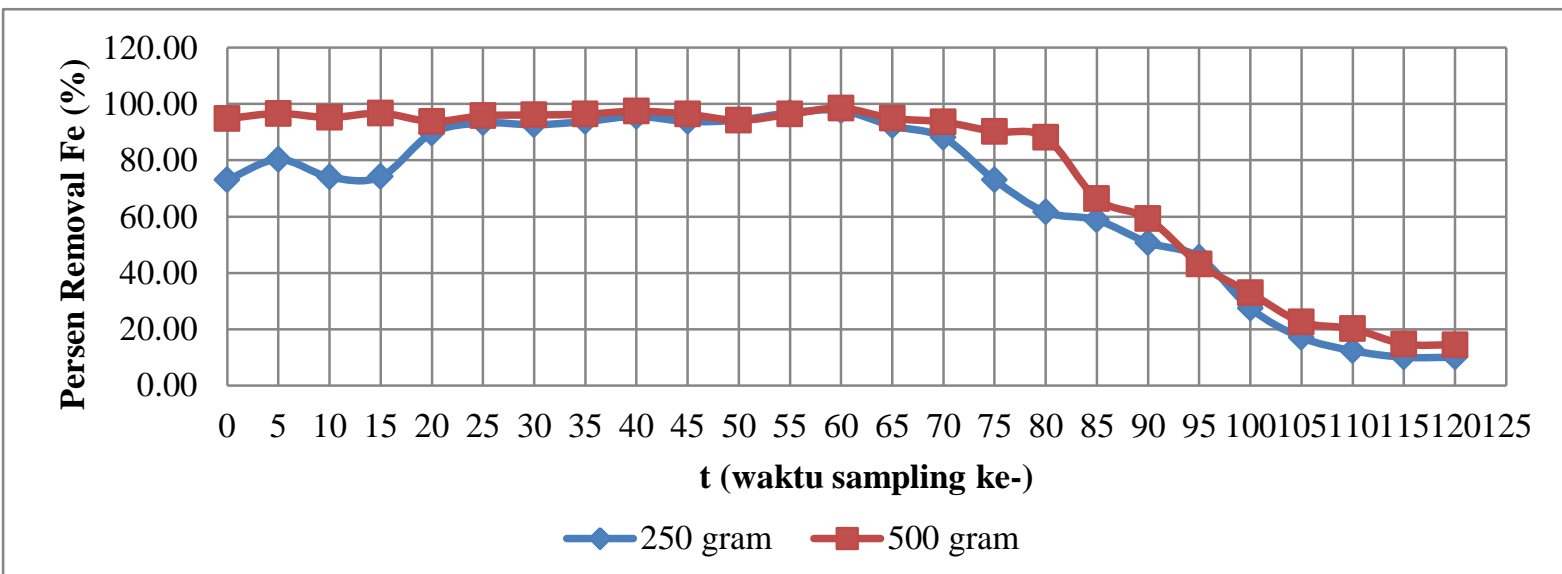

Gambar 2. Hubungan persen removal Fe terhadap waktu sampling pada variasi massa 250 gram dan 500 gram.

Waktu sampling 0 menit didapatkan setelah air sumur tepat keluar dari unggun dan pengambilan dilanjukan berturut turut dalam selang waktu 5 menit selama 120 menit sehingga didapatkan waktu sampling sebanyak 25 waktu sampling. Hasil penyisihan Fe menggunakan adsorben kulit kacang tanah tersebut memiliki sebaran nilai yang merata ditandai dengan sebaran nilai yang tidak jauh berbeda satu sama lain. Dan penyisihan Fe tertinggi menggunakan adsorben kulit kacang tanah ini didapatkan pada saat sampling ke-13 yakni tepat pada menit ke-60 yang memiliki persen penyisihan $\mathrm{Fe}$ sebanyak $98,52 \%$ nilai tersebut didapatkan pada saat penggunaan massa sebanyak 500 gram, sedangkan pada saat penggunaan massa adsorben 250 gram, didapatkan persen penyisihan tertinggi menggunakan adsorben kulit kacang tanah sebesar 97,67\% tepat pada menit ke-60 juga. Pada penggunaan adsorben $250 \mathrm{mg}$, diawal waktu \%removal sebesar 70\% terus naik dan stabil saat 20 menit. Hal ini berbeda dengan adsorben $500 \mathrm{mg}$ yang cenderung stabil mulai dari awal proses. Hal ini disebabkan karena dengan debit yang relatif cepat dinilai menyebabkan persebaran air sumur ke setiap adsorben dalam kolom adsorbsi dengan diameter $10,5 \mathrm{~cm}$ kurang merata pada titik awal proses. 
Hal tersebut sesuai dengan hasil beberapa penelitian terdahulu, bahwa semakin banyak jumlah adsorben yang digunakan, maka semakin luas permukaan adsorben yang digunakan untuk proses adsorbsi dan hal tersebut menyebabkan banyaknya jumlah adsorbat yang terserap karena tumbukan antara partikel adsorbat dan adsorben meningkat (Lestari et al., 2017). Hal tersebut sesuai dengan penelitian sebelumnya yang menyatakan bahwa peningkatan jumlah karbon aktif yang digunakan pada proses adsorpsi menyebabkan peningkatan pula pada persen penyisihan adsorbat. Pada penelitian ini, didapatkan waktu jenuh yang relatif cepat hal tersebut disebabkan oleh laju alir dari inffluent yang cukup tinggi sehingga proses difusi yang terjadi pada permukaan adsorben tidak bisa dilakukan dalam waktu yang cukup lama dan hal tersebut menyebabkan proses adsorpsi kurang maksimal (Ariska, Hadiwidodo, \& Wardhana, 2012).

Gambar 2 juga menunjukkan bahwa kondisi jenuh pertama kali dicapai pada proses adsorpsi dengan massa 250 gram. Hal tersebut menunjukkan bahwa luas permukaan berpengaruh terhadap proses adsorbsi. Semakin luas permukaan adsorben, maka semakin lama waktu jenuh dicapai pada proses tersebut. Adapun penjelasan terkait dengan kurva breaktrough dimana break point ditunjukkan pada rasio $\mathrm{Cn} / \mathrm{Co}$ yang mendekati $5 \%$. Hal tersebut dapat dilihat pada Gambar 3.

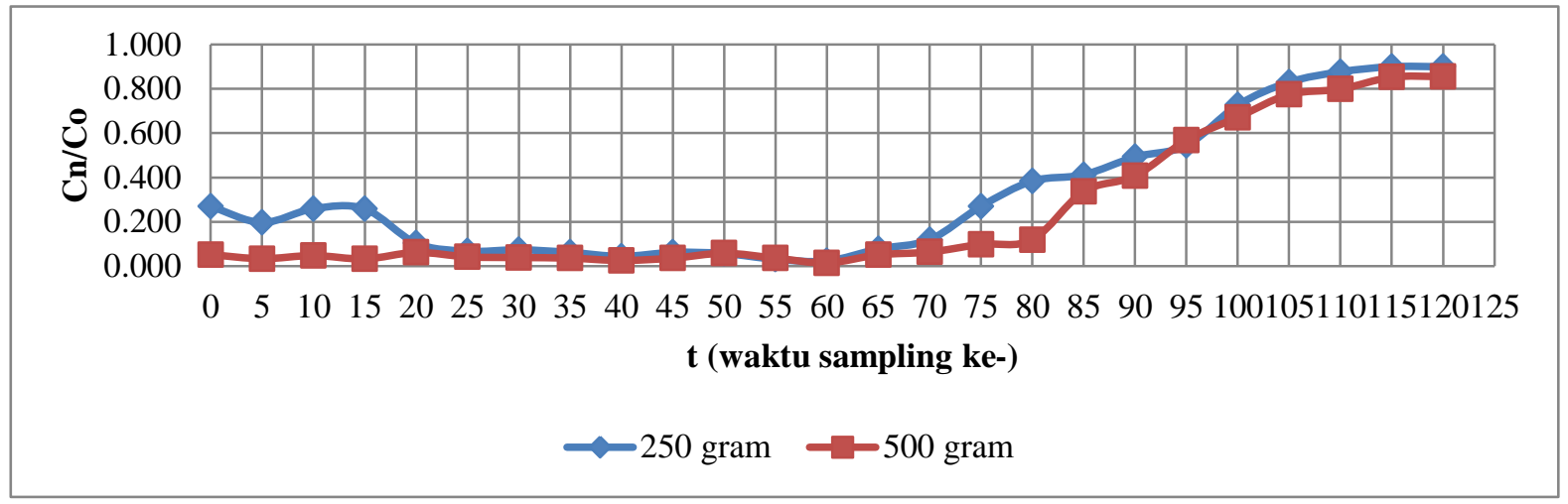

Gambar 3. Kurva breakthrough pada effluent dari proses adsorpsi Fe

Gambar 3 menunjukkan bahwa break point dicapai oleh adsorben dengan massa 250 gram dan 500 gram dengan $\mathrm{Cn} / \mathrm{Co}$ sebesar 0,04 dan 0,03 berturut-turut pada waktu sampling ke 13 yakni pada waktu 60 menit setelah air sumur keluar dari unggun. Sedangkan titik jenuh atau exhaustion time pada penelitian ini merupakan waktu dimana kolom adsorpsi mendekati kejenuhan yang ditunjukkan pada menit ke 115 pada kedua variasi massa yakni pada waktu sampling ke-24 dengan perbandingan $\mathrm{Ct} / \mathrm{Co}$ senilai 0,899 pada penggunaan massa 250 gram dan senilai 0,855 pada penggunaan massa 500 gram. Sehingga dari hasil tersebut, menunjukkan bahwa penggunaan adsorben kulit kacang tanah pada sekali penggunaan dapat digunakan dalam waktu 120 menit dengan laju alir 0,2 L/menit ketika ukurannya \pm 50 mesh.

\subsection{Penentuan Kapasitas Adsorbansi Optimum dengan Model Thomas}

Desain kolom tetap atau fixed bed melibatkan perkiraan bentuk kurva breakthrough dan tampilan breakpoint, yang merupakan faktor penting dalam menggetahui kelayakan penggunaan adsorben dalam aplikasi nyata. Untuk ketinggian kolom, plot konsentrasi keluar terhadap waktu yang dilalui atau volume yang melewati proses yang direaksikan dikenal sebagai kurva breakthrough (Arie, 2016). Untuk menjelaskan perilaku kolom fixed bed dan untuk meningkatkan pada aplikasi skala industri, dibutuhkan model yang tepat untuk digunakan. Pada penelitian ini, kinetika sistem adsorpsi yang terjadi pada fixed-bed column dianalisis dengan menggunakan Model Thomas yang merupakan salah satu model teori kinerja kolom yang paling umum digunakan. Adapun rumus yang digunakan dapat dilihat pada persamaan 3. Dari persamaan tersebut, maka didapatkan hasil berupa grafik yang dapat dilihat pada Gambar 4.

Grafik yang terdapat pada gambar 4 digunakan untuk perhitungan persamaan Thomas dengan hasil konstanta kinetik (Kth) dan kapasitas adsorbansi kolom (qth) model Thomas pada berbagai kondisi percobaan adsorpsi Fe pada air sumur dengan variasi adsorben dalam fixed-bed column dijelaskan pada Tabel 1. 


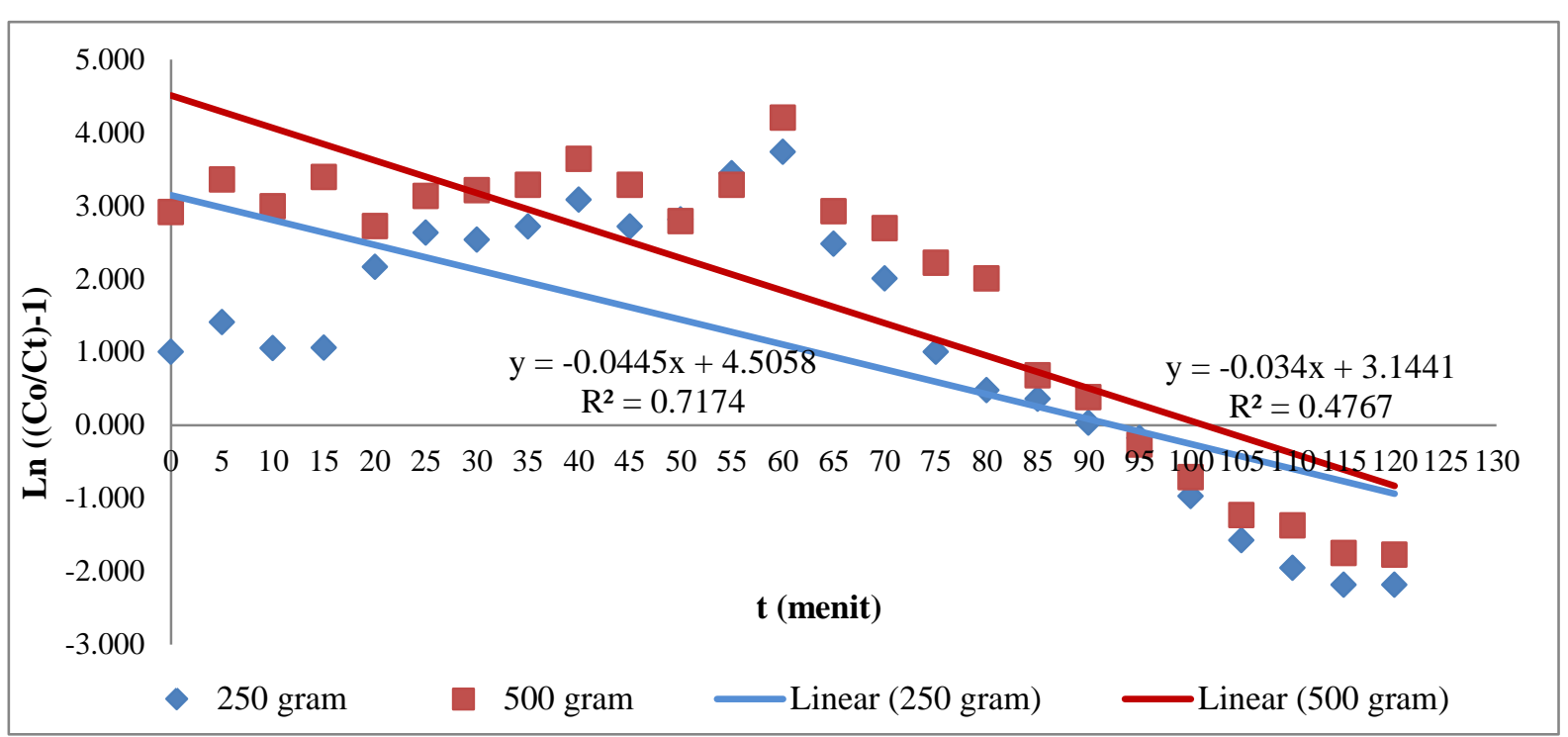

Gambar 4. Hasil Perhitungan kapasitas adsorbansi dengan persamaan Thomas pada variasi massa adsorben.

Tabel 1. Parameter Model Thomas

\begin{tabular}{|c|c|c|c|c|c|}
\hline \multirow{2}{*}{ Jenis adsorben } & Massa adsorben (x) & Persamaan linear & \multirow{2}{*}{$\mathbf{R}^{2}$} & \multirow{2}{*}{$\begin{array}{l}\text { Kth } \\
\text { (L/mg/ } \\
\text { menit) }\end{array}$} & qo \\
\hline & gram & $\mathbf{Y}$ & & & mg/gram \\
\hline $\begin{array}{l}\text { Karbon Aktif } \\
\text { Kulit Kacang Tanah }\end{array}$ & 250 & $-0.2224 x+4.7282$ & 0.7174 & 0.10755 & 0.016115626 \\
\hline $\begin{array}{l}\text { Karbon Aktif } \\
\text { Kulit Kacang Tanah }\end{array}$ & 500 & $-0.1701 x+3.3142$ & 0.4767 & 0.08226 & 0.035169308 \\
\hline
\end{tabular}

Tabel 1 merupakan data konstanta Thomas dan kapasitas adsorbansi yang didapatkan dari persamaan Thomas dari kedua variasi massa adsorben dalam fixed-bed column. Nilai konstanta Kth dan $\mathrm{q}_{\mathrm{o}}$ dapat diketahui melalui nilai slope dan intercept dari persamaan yang ditunjukkan oleh gambar 4. Dari hasil yang didapatkan tersebut, konstanta Thomas pada kedua variasi massa dinilai tidak berbeda secara signifikan hal tersebut dikarenakan letak titik jenuh yang didapatkan tidak terlampau jauh antara kedua massa yang digunakan. Dan berdasarkan hasil koefisien determinasi $\left(\mathrm{R}^{2}\right)$ yang didapatkan dari grafik antara rentang waktu sampling dengan $(\mathrm{Ln}(\mathrm{Co}-\mathrm{Ct})$ 1)) yang menunjukkan nilai 0,48 hingga 0,72 menunjukkan bahwa variabel rentang waktu yang digunakan oleh peneliti tidak mampu menjelaskan variabel ( $\mathrm{Ln}(\mathrm{Co}-\mathrm{Ct})-1)$ ) dengan baik yakni sekitar $48 \%$ hingga $72 \%$ (Fatkhan, 2017), sehingga diperlukan rentang waktu yang lebih lama untuk mengetahui hubungan kausalitasnya lebih teliti. Hal ini dikarenakan waktu penelitian yang dinilai sangat singkat yakni 2 jam dan juga dikarenakan jarang waktu sampling satu sama lain hanya sekitar 5 menit. Dari perhitungan persamaan Thomas diatas juga dapat disimpulkan bahwa kapasitas adsorbansi tertinggi dicapai pada penggunaan adsorben sebanyak 500 gram karbon aktif kulit kacang tanah, yakni sebanyak $0.035 \mathrm{mg} /$ gram yang artinya dalam 1 gram adsorben karbon aktif komersial mampu menyerap $0.035 \mathrm{mg}$ adsorbat Fe. Sedangkan pada variasi penggunaan adsorben kulit kacang tanah 250 gram, didapatkan nilai sebesar $0.1611 \mathrm{mg} / \mathrm{gr}$. Perbedaan hasil kapasitas adsorbansi dari kedua variasi massa yang cukup sedikit dikarenakan konsentrasi influent yang cukup kecil sehingga menyebabkan penyisihan Fe dapat berlangsung cukup maksimal dengan persen removal dan kapasitas jerat yang cukup tinggi.

Hasil kapasitas adsorbsi tersebut menunjukkan penggunaan karbon aktif kulit kacang tanah dapat menjadi alternatif sebagai adsorben untuk menurunkan logam berat pada air baku hingga persen penyisihan 90\%. Selain itu, dalam proses penyisihan Fe sendiri mekanisme yang berperan dalam proses adsorpsi ini yakni adanya ikatan Van der Waals, yang merupakan salah satu jenis ikatan inter-molekuar yang ada pada proses adsorpsi fisika seperti pada percobaan kali ini. Ikatan Van der Waals sendiri merupakan gaya tarik antar molekul akibat tarikan dipol-dipol. Molekul dipolar cenderung untuk mengikat molekul tetangganya, hingga kutub negatif suatu molekul mendekati kutub positif molekul lainnya. Karbon aktif yang terdiri atas karbon yang memiliki muatan 
netral, yang berarti mengandung muatan negatif dan muatan positif dalam jumlah yang seimbang. Konsentrasi $\mathrm{Fe}$ pada penelitian terdiri atas $\mathrm{Fe}^{2+}$ dan $\mathrm{Fe}^{3+}$ terlarut yang memiliki muatan positif. Berdasarkan prinsip ikatan Van der Waals, muatan positif yang dimiliki oleh $\mathrm{Fe}$ akan berikatan dengan muatan negatif pada karbon aktif (Maesara \& Kunaefi, 2018). Pada adsorpsi fisika sendiri, keseimbangan antar permukaan padatan dengan molekul fluida cenderung cepat tercapai sehingga cepat terjadi kejenuhan. Hal tersebut juga tentu didukung oleh faktor-faktor yang mempengaruhi proses adsorpsi itu sendiri, seperti laju alir dan luas permukaan adsorben.

\section{KESIMPULAN DAN SARAN}

\subsection{Kesimpulan}

Berdasarkan hasil penelitian dan pembahasan yang telah dikerjakan, dapat diketahui bahwa penyisihan $\mathrm{Fe}$ maksimum didapatkan pada variasi massa 500 gram karbon aktif kulit kacang tanah pada menit ke-60 dengan persen penyisihan $98,52 \%$. Hal tersebut menunjukkan bahwa adsorben dari limbah kulit kacang tanah dapat dijadikan alternatif adsorben papa proses penjernihan air baku. Sedangkan titik breakthrough adsorben kulit kacang tanah pada penyisihan Fe didapatkan pada menit ke-60 sedangkan exhaustion time-nya yakni pada menit ke-115. Hal tersebut menunjukkan waktu regenerasi dari adsorben agar adsorben tersebut dapat digunakan kembali untuk proses adsorpsi logam Fe pada penggunaan selanjutnya. Dan persamaan sesuai model Thomas yang sesuai untuk penyisihan Fe pada air sumur menggunakan kulit kacang tanah yaitu $\mathrm{y}=-0.1701 \mathrm{x}+3.3142$ dengan nilai $R^{2}=0,467$, dengan konstantha Thomas senilai 0,08226 dan kapasitas adsorbansi maksimum yaitu $0,035 \mathrm{mg} / \mathrm{gram}$.

\subsection{Saran}

Dalam penelitian kali ini telah dilakukan dengan debit aliran tetap dan hanya pada penyisihan logam $\mathrm{Fe}$, sehingga diperlukan penelitian lebih lanjut terkait dengan penggunaan adsorben kulit kacang tanah pada penyisihan logam berat atau kandungan pencemar lainnya, serta perlu dipelajari interaksi antara adsorben dan adsorbat melalui analisa SEM. Selain itu, perlu dipelajari terkait dengan pengaruh ukuran pori dan distribusi ukuran pori dari adsorben serta pengaruh aktivasi bahan kimia terhadap penurunan zat pencemar baik logam maupun zat organic lainnya.

\section{UCAPAN TERIMA KASIH}

Ucapan terima kasih disampaikan kepada Lembaga Penelitian dan Pengabdian Kepada Masyarakat (LPPM) UPN "Veteran" Jawa Timur untuk pendanaan penelitian ini melalui skema Hibah Riset Dasar (Risda) dengan nomor kontrak No. SPP/21/UN.63.8/LT/IV/2019.

\section{REFERENSI}

Adeyemo, A.A., Adeoye, I.O., \& Bello, O.S. (2017). Adsorption of dyes using different types of clay: A review. applied water science, 7, 543-568.

Ariska, D., Hadiwidodo, M., \& Wardhana, I. W. (2012). Pemanfaatan residu bahan bakar batu bara (bottom ash) sebagai adsorben zat warna reaktif dan logam berat $(\mathrm{Cu}$ dan $\mathrm{Ni})$ dari limbah cair tekstil dengan reaktor sistem kontinyu (studi kasus: limbah cair PT. Apac Inti Corpora), Universitas Diponegoro.

Asnawati, A. (2017). Penentuan kapasitas adsorpsi selulosaterhadaprhodamin B dalam sistem dinamis. Jurnal Kimia Riset, 2(1), 23-29.

Amalia, A., Maharani, P.A., Hidayah, E.N. \& Putro, R.K.H. (2018). Modeling of isoterm phosphate adsorption in laundry wastewater using anion resin. Proceedings of the International Conference on Science and Technology. Atlantis Press. https://doi.org/10.2991/icst-18.2018.49.

Biswas, S. \& Mishra, U. (2015). Continuous fixed-bed column study and adsorption modelling: removal oflead ion from aqueous solution by charcoal originated from chemical carbonization of rubber wood sawdust. Journal of Chemistry. http://dx.doi.org/10.1155/2015/907379.

Dewati, R., Ragilia, R. P., Kharisma, T., \& Wahyusi, K. N. (2012). Briket arang kulit kacang tanah dengan proses karbonisasi. Jurnal Teknik Kimia, 6(2).

Fatkhan Amirul Huda. (2017, Maret). Koefisien determinasi pada regresi linear. Dikutip 18 Oktober 2019, dari http://fatkhan.web.id/koefisien-determinasi-pada-regresi-linear/. 
Hidayati, P., Ulfin, I., \& Juwono, H. (2016). Adsorpsi zat warna remazol Brilliant Blue R menggunakan Nata De Coco: optimasi dosis adsorben dan waktu kontak. Jurnal Sains Dan Seni Its, 5(2).

Lestari, S., Susatyo, E. B., \& Prasetya, A. T. (2017). Sintesis arang aktif kulit kacang tanah untuk menurunkan kadar sulfida interferensi sianida. Indonesian Journal Of Chemical Science, 6(1), 34-37.

Maesara, S. A., \& Kunaefi, T. D. (2018). Penyisihan besi dan zat organik menggunakan karbon aktif dari kulit durian sebagai media filtrasi removal of iron and organic matter by activated carbon from durian peels as filtration media. Jurnal Teknik Lingkungan, 18(2), 167-177.

Mizwar, A. (2016). Penyisihan warna pada limbah cair sasirangan dengan adsorpsi zeolit dalam fixed-bed column. Enviroscienteae, 9(1), 1-9.

Pricilia Duma Laura, S. S. M., Cindy R. Priadi. (2014). Adsorpsi dan regenerasi karbon aktif dalam pengolahan air limbah industri farmasi terhadap penurunan kadar chemical oxygen demand. FT UI.

Safrianti, I., Wahyuni, N., \& Zaharah, T. A. (2012). Adsorpsi timbal (Ii) oleh selulosa limbah jerami padi teraktivasi asam nitrat: Pengaruh $\mathrm{pH}$ dan waktu kontak. Jurnal Kimia Khatulistiwa, 1(1).

Sagita, Ruana.(2017, 25 Juni). 9 daerah penghasil kacang tanah di Indonesia. Dikutip 20 Februari 2019, dari https://ruanasagita.blogspot.com/2017/06/9-daerah-penghasil-kacang-tanah-di.html.

Susilawaty, A., Amansyah, M., \& Jumiati, J. (2015). Peningkatan kualitas air sumur gali berdasarkan parameter besi (Fe) dengan pemanfaatan kulit pisang kepok di Dusun Alekanrung Desa Kanrung Kabupaten Sinjai. Al-sihah: The Public Health Science Journal, 7(2).

Zuhroh, N., Prasetya, A., \& Haryani, S. (2016). Adsorpsi krom (vi) oleh arang aktif serabut kelapa serta imobilisasinya pada batako. Jurnal Mipa, 39(1), 57-62. 